\title{
Feeding style of adolescent mothers and complementary feeding practice of their infants
}

\author{
Estilo alimentar adotado por mães adolescentes \\ e práticas da alimentação complementar \\ dos seus filhos lactentes
}

Karla Adriana Oliveira da COSTA ${ }^{1}$ (D) 0000-0001-5585-5768

Margarida Maria de Castro ANTUNES1 (iD) 0000-0001-5785-9906

Poliana Coelho CABRAL ${ }^{2}$ (D) 0000-0002-2709-4823

Giselia Alves Pontes da SILVA 1 (ID) 0000-0002-5310-3420

\section{A B S T R A C T}

\section{Objective}

To evaluate feeding styles of adolescent mothers and complementary feeding practices of their infants.

\section{Methods}

A cross-sectional study comparing a group of dyads of 50 adolescent mothers (ages 15 to 19) with 62 adult mothers (ages 24 to 44) and their infants (9 to 24 months) was performed. All mothers and infants were assisted by three basic health family units in the city of Recife, Brazil. Data were collected through a structured interview on socioeconomic conditions, maternal styles of feeding the child, and evaluation of infant feeding practices. The food styles were classified as responsive, authoritative, and passive, according to the adapted form of

\footnotetext{
1 Universidade Federal de Pernambuco, Centro de Ciências da Saúde, Programa de Pós-Graduação em Saúde da Criança e do Adolescente. Av. Professor Rego de Moraes, 1235, Cidade Universitária, 50670-901, Recife, PE, Brasil. Correspondência paral Correspondence to: KAO COSTA. E-mail: <karla.costa.nutricao@hotmail.com>.

2 Universidade Federal de Pernambuco, Departamento de Nutrição, Programa de Pós-Graduação em Nutrição. Recife, PE, Brasil.

Article based on the master's thesis of KAO COSTA, entitled: "Prática alimentar do lactente: influência do estilo parental e estilo de alimentar adotado por mães adolescentes”. Universidade Federal de Pernambuco; 2016.
}

Como citar este artigo/How to cite this article

Costa KAO, Antunes MMC, Cabral PC, Silva GAP. Feeding style of adolescent mothers and complementary feeding practice of their infants. Rev Nutr. 2018;31(1):49-58. https://doi.org/10.1590/1678-98652018000100005 
Carvalhaes, Perosa and Silveira of 2009. The frequency of food intake was calculated for six food groups (1. Bread and cereals; 2. Fruits and vegetables; 3. Meat, eggs, and beans; 4. Milk and dairy products; 5 . Sugars, sweets, and fats; 6 . Industrialized food). Children's anthropometry and body mass index by age were classified into Z-score according to the World Health Organization Standard Curves, 2006.

\section{Results}

Adolescent mothers began complementary feeding more frequently before the seventh month $(p=0,02)$, presented less responsive $(p=0.04)$ and more authoritarian feeding styles $(p=0.01)$, and their children received more foods with sugars, oils, and fats $(p=0.02)$, and less meat, eggs, and beans $(p=0.06)$ than the children of adult mothers.

\section{Conclusion}

Adolescent mothers adopt less responsive eating styles and offer more inadequate complementary feeding for their infants.

Keywords: Adolescent. Child care. Maternal behavior. Supplementary feeding.

\section{R E S U M O}

\section{Objetivo}

Este artigo tem como objetivo avaliar os estilos alimentares adotados por mães adolescentes e as práticas e consumo alimentar dos seus filhos lactentes.

\section{Métodos}

Trata-se de estudo de corte transversal, comparando um grupo de díades de 50 mães adolescentes (15 a 19 anos) e outro de 62 mães adultas (24 a 44 anos) e seus filhos lactentes (9 a 24 meses), atendidos em três unidades de Saúde da Familia da Cidade do Recife. As mães foram entrevistadas para obtenção de dados socioeconômicos e das práticas alimentares, avaliadas pelos Indicadores de Práticas Alimentares Infantis da Criança Pequena. Os estilos alimentares foram classificados em responsivo, autoritário e passivo, segundo formulário adaptado de Carvalhaes, Perosa e Silveira de 2009. Foi calculada a frequência de consumo alimentar para seis grupos de alimentos (1. Pães e cereais; 2. Frutas, legumes e verduras; 3. Carnes, miúdos, ovos e feijão; 4. Leite e produtos lácteos; 5. Açúcares, doces e gorduras; 6. Industrializados). Realizou-se antropometria das crianças, e o índice de massa corporal por idade foi classificado em escore-Z de acordo com as curvas padrão da Organização Mundial de Saúde, 2006.

\section{Resultados}

As mães adolescentes iniciaram alimentação complementar mais frequentemente antes do sétimo mês $(p=0,02)$, apresentaram estilos menos responsivos $(p=0,04)$ e mais autoritários de alimentação $(p=0,01)$. Seus filhos receberam mais alimentos com açúcares, óleos e gorduras $(p=0,02)$, sendo observada tendência a menor oferta de carnes, miúdos, ovos e feijão $(p=0,06)$ do que aos filhos de mães adultas.

\section{Conclusão}

Mães adolescentes adotam estilos alimentares menos responsivos e oferecem alimentação complementar mais inadequada para seus filhos lactentes.

Palavras-chave: Adolescente. Cuidado da criança. Comportamento materno. Suplementação alimentar.

\section{NTRODUCTION}

Feeding is more than nutritional intake and is influenced by cultural, socioeconomic and affective aspects $[1,2]$. The interaction of mother with her baby in early life is a key factor for establishment of child's feeding patterns. The mother, in most cases, is who that selects, prepares, and provides food and, therefore, determines the location, quantity, form and context in which the child will feed. So, the practices adopted by the mother may encourage 
or discourage infant's healthy feeding behaviors $[3,4]$.

Parent's behavior when are feeding their children are designated feeding practices or dietary parental styles of feeding. These, can be defined as responsive or sensitive when considered positive, and non-responsive when infused with authoritarianism, passivity or restrictions [5,6]. A non-responsive style was associated with a lower stimulation of healthy food choices by children, as well as, a worse infant's regulation of hunger and satiety $[7,8]$. Thus, the dietary parental style of complementary feeding may be associate with malnutrition and overweight in childhood, and obesity and metabolic syndrome for a lifetime [9].

To choose, consciously or unconsciously, how to feed her child can be a challenging moment for mothers, especially adolescents. Adolescent mothers are faced with greater social and economic vulnerabilities, and, probably have cognitive and emotional immaturity, that leads to special affective interactions with their babies. In the context of adolescent motherhood, it is more probable that parents adopt inappropriate eating styles for complementary feeding, which can determine consequences on the child's health for life $[10,11]$. Therefore, this study aims to evaluate the feeding styles adopted by adolescent and adult mothers, and feeding practices of their infants during the complementary feeding period.

\section{METHODS}

A cross-sectional study, comparing dyads of 50 adolescent mothers (ages 15 to 19) with 62 adult mothers (ages 24 to 44 ) and their infants (from nine to 24 months) was conducted. All of them were attended in three family health units in Recife Northeast of, Brazil. The dyads were identified by the 2005 census for children up to two years old managed by Community Health Workers from January to June 2015. The mothers evaluated were the main caregivers and responsible for feeding their infants. Mothers with cognitive deficits or mental illness, and children with chronic diseases that could interfere with feeding process were excluded.

The data were obtained by a structured formulary that assessed sociodemographic characteristics (age, number of children, cohabitation with the child's father, contribution to home income, years of schooling, readability and support in the care of the child), orientations received about nutrition and feeding practices of small children, assessment of food style adopted, and a questionnaire for evaluation of frequency of food intake. All data were collected by the same researcher, a trained nutritionist.

The research was approved by the Human Research Ethics Committee at the Health Sciences Center of the Universidade Federal de Pernambuco with CAEE n 900.835 in December 2014. Mothers older than age 18 signed the Informed Consent Form and those younger than 18, signed a Free and Informed Assent Form.

\section{Evaluation of infant feeding practices}

The guidelines of the Indicators for Assessing Infant and Young Child Feeding Practices, proposed by the World Health Organization [12], were used as a reference to assess infant feeding practices. The formulary relating to feeding practices was composed of questions about the orientation of health professionals regarding breastfeeding and complementary feeding, duration of breastfeeding, age at introduction of non-dairy foods, use of formulas or cow milk, and consistency of diet.

\section{Evaluation of maternal styles of feeding small children}

For the assessment of maternal feeding styles, an adaptation of the Carvalhaes et al. 
[13] observational script was carried out.The adaptation was performed by researchers analysis and decision, and the modification consisted of transformation of the original observational script into questions, excluding items that could not be observed in the age of the children evaluated. The adapted formulary included questions related to the context of feeding, kinds of food, feeding styles, and interactive sequences. These observations were grouped into topics: environment where the meal was served; food, utensils and furniture used; position of dyads; if occurs encouraging behavior for the intake of food and verbal and visual communication forms; maternal behaviors when dealing with the refusal of the child to eat; behavior in search for autonomy; maternal adaptation facing the responses and initiatives; and child behaviors that led to the end of the meal.

The maternal feeding styles were classified into responsive, passive, and authoritarian, according concepts accepted by current literature $[14,15]$. The final questionnaire consisted of 17 questions related to the responsive style and 10 related to the non-responsive style (seven for the authoritarian and three to passive). Each question included five response options: Never, Rarely, Sometimes, Often, and Always. A value of zero to four was assigned to each. Subsequently, the distribution of the total sum of responses of each style was obtained establishing the scores of positive responses for each style by patients, and using the medians and interquartile ranges for comparison.

\section{Assessment of food intake}

Assessment of food intake was performed by the method of Fornés [16], for frequency of intake. Six food groups established by the Brazilian Food Guide for Children Under Two Years of Age were analyzed [17]. Group I was comprised of breads and cereals; Group ॥ comprised fruits, vegetables, and greens; Group
III included meats, offal, eggs, and beans; Group IV comprised milk and dairy products; Group V included sugars, sweets, oils, and fats; and Group VI was made up of processed foods. The values were obtained in frequency of weekly intake, which was later transformed into monthly intake (number of times the food was consumed in the month).

\section{Anthropometric assessment}

Weight was measured using a portable electronic scale with capacity of $180 \mathrm{~kg}$ and precision of $100 \mathrm{~g}$ (Plenna ${ }^{\circledR}$ ) (Plenna Especialidades, São Paulo, SP, Brasil). The children were weighed unclothed and their mothers without shoes. For children under 24 months, initially, only the mother was weighed-positioned facing the examiner, in the center of the equipment, erect, with feet together and arms extended along the body and then with the child, calculating the difference between these two measurements. For children older than 24 months, the weight was evaluated in the same way as measured with the mother.

Regarding height, children less than 24 months were measured in a dorsal decubitus position in a pediatric anthropometer, and older children were measured with an inextensible and inelastic tape.

Body Mass Index (BMI) was obtained dividing the weight $(\mathrm{kg})$ by the height $(\mathrm{m})$ [2]. BMI Z-scores were categorized according to the World Health Organization, 2005 [18], in leanness ( $\geq Z$-score -3 and $<Z$-score -2 ), eutrophy ( $\geq Z$-score -2 and $\leq Z$-score +2 ), and overweight (>Z-scores +2$)$. The World Health Organization Anthro Plus software was used to classify BMl/ age into Z-scores

\section{Statistical analysis}

The collected data were entered in duplicates in the Epi Info statistical package 
version 3.5.1 (Center For Disease Control/World Health Organization - CDCMHO, Atlanta, GA, USA), and subsequently the mode validate was used to review possible inconsistencies in typing. The data analysis was performed using the Statistical Package for the Social Sciences (SPSS) statistical package Epi Info and SPSS International Business Machines Corporation (IBM).

The chi-square test or Fisher's exact test was used to compare the frequencies between groups, when indicated. The quantitative variables (age of mothers and children, scores of feeding styles, and frequency of food intake) were tested for normal distribution using the KolmogorovSmirnov test and all, excluding the age of the children, presented a non-normal distribution, thus being described as median and quartiles, and compared between the groups by means of the Mann-Whitney test. The age of the children was described as mean and standard deviation, and was not tested. A significance of $p<0.05$ was set.

Table 1. Socioeconomic and demographic characteristics of adolescent and adult mothers attended in three Basic Health Units in the city of Recife (PE), 2015.

\begin{tabular}{|c|c|c|c|c|c|c|c|}
\hline \multirow{2}{*}{ Characteristics } & \multicolumn{2}{|c|}{ Adolescent mothers $(n=50)$} & \multicolumn{2}{|c|}{ Adult mothers $(n=62)$} & \multicolumn{2}{|c|}{ Total $(n=112)$} & \multirow{2}{*}{$p$} \\
\hline & $\mathrm{n}$ & $\%$ & $\mathrm{n}$ & $\%$ & $\mathrm{n}$ & $\%$ & \\
\hline \multicolumn{8}{|l|}{ Number of Children } \\
\hline 1 & 32 & 64.0 & 23 & 37.0 & 55 & 49.0 & $<0.01^{*}$ \\
\hline$\geq 2$ & 18 & 36.0 & 39 & 63.0 & 57 & 51.0 & \\
\hline \multicolumn{8}{|l|}{ Cohabitation with the companion } \\
\hline No & 8 & 16.0 & 13 & 21.0 & 21 & 19.0 & $0.33^{*}$ \\
\hline Yes & 42 & 84.0 & 49 & 79.0 & 91 & 81.0 & \\
\hline \multicolumn{8}{|l|}{ Contribution to the family income } \\
\hline Does not work & 41 & 82.0 & 51 & 82.0 & 92 & 82.0 & $0.56^{* *}$ \\
\hline Works and has financial aid & 5 & 10.0 & 4 & 6.4 & 9 & 8.0 & \\
\hline Is the sole financial provider & 4 & 8.0 & 7 & 11.0 & 11 & 9.8 & \\
\hline \multicolumn{8}{|l|}{ Maternal schooling } \\
\hline Basic education or less & 11 & 22.0 & 14 & 23.0 & 25 & 22.0 & $0.88^{*}$ \\
\hline Secondary schooling or higher & 39 & 78.0 & 48 & 77.0 & 87 & 78.0 & \\
\hline \multicolumn{8}{|l|}{ Maternal Literacy } \\
\hline Reads with difficulty & 11 & 22.0 & 9 & 15.0 & 20 & 18.0 & $0.27^{*}$ \\
\hline Reads with ease & 39 & 78.0 & 53 & 86.0 & 92 & 82.0 & \\
\hline \multicolumn{8}{|l|}{ Economic Situation $^{* * *}$} \\
\hline Bottom lower & 4 & 8.0 & 3 & 4.8 & 7 & 6.3 & $0.38^{* *}$ \\
\hline Upper lower & 46 & 92.0 & 59 & 95.0 & 10 & 94.0 & \\
\hline \multicolumn{8}{|l|}{ Support in child care } \\
\hline Yes & 47 & 94.0 & 51 & 82.0 & 98 & 88.0 & $0.06^{* *}$ \\
\hline No & 3 & 6.0 & 11 & 18.0 & 14 & 13.0 & \\
\hline
\end{tabular}

Note: ${ }^{*}$ Chi square; Statistically significant; ${ }^{* *}$ Fishers Exact Test; ${ }^{* * *}$ Poverty levels proposed by Alvarez et al. [19]. 


\section{RE S U L T S}

Fifty dyads of adolescent mothers (median age $=19$ years) and 62 of adult mothers (median age $=30$ years) participated in the study. Both groups had a similar socioeconomic and demographic profile, except for the size of offspring, which was higher among adult mothers $(p<0.01)$, and a higher frequency of support in caring for the child was received by adolescent mothers $(p=0.06)$ (Table 1$)$. The age of 112 children presented normal distribution and its mean (Standard Deviation - SD) was 16 (5) months.

Of the children assessed, $17.8 \%$ had excess weight and $5.4 \%$ were of normal weight; however, there was no difference in the frequency of these changes among children of adolescent and adult mothers. Of the total

Table 2. Nutritional status and feeding practices of infants born to adolescent and adult mothers attended at three Family Health Units. Recife (PE), 2015.

\begin{tabular}{|c|c|c|c|c|c|c|c|}
\hline \multirow[t]{2}{*}{ Variables } & \multicolumn{2}{|c|}{$\begin{array}{l}\text { Teenage Mothers } \\
\qquad(n=50)\end{array}$} & \multicolumn{2}{|c|}{$\begin{array}{l}\text { Adult mothers } \\
\qquad(n=62)\end{array}$} & \multicolumn{2}{|c|}{ Total } & \multirow[t]{2}{*}{$p$} \\
\hline & $n$ & $\%$ & $\mathrm{n}$ & $\%$ & $\mathrm{n}$ & $\%$ & \\
\hline \multicolumn{8}{|c|}{ BMI Classified according to Z-score ${ }^{* *}$} \\
\hline Thinness & 3 & 6.0 & 3 & 4.8 & 6 & 5.36 & \multirow{3}{*}{0.65} \\
\hline Eutrophy & 41 & 82.0 & 45 & 73.0 & 86 & 76.80 & \\
\hline Excess weight & 6 & 12.0 & 14 & 23.0 & 20 & 17.90 & \\
\hline \multicolumn{8}{|c|}{ Guidance on breastfeeding } \\
\hline No & 10 & 20.0 & 9 & 15.0 & 19 & 17.00 & \multirow{4}{*}{0.70} \\
\hline Doctor & 3 & 6.0 & 7 & 11.0 & 10 & 8.90 & \\
\hline Nurse & 36 & 72.0 & 45 & 73.0 & 81 & 72.30 & \\
\hline Health Agent & 1 & 2.0 & 1 & 1.6 & 2 & 1.80 & \\
\hline \multicolumn{8}{|c|}{ Guidance on the introduction of food } \\
\hline No & 8 & 16.0 & 13 & 21.0 & 21 & 18.80 & \multirow{4}{*}{0.32} \\
\hline Doctor & 5 & 10.0 & 7 & 11.0 & 12 & 10.60 & \\
\hline Nurse & 35 & 70.0 & 40 & 65.0 & 75 & 67.00 & \\
\hline Other & 2 & 4.0 & 2 & 3.2 & 4 & 3.60 & \\
\hline \multicolumn{8}{|c|}{ Introduction of non-dairy foods (months) } \\
\hline$\leq 5$ & 30 & 63.0 & 47 & 76.0 & 77 & 70.00 & \multirow{3}{*}{$0.02^{*}$} \\
\hline 6 & 14 & 29.0 & 6 & 9.7 & 20 & 18.20 & \\
\hline $7-11 v$ & 4 & 8.3 & 9 & 15.0 & 13 & 11.80 & \\
\hline \multicolumn{8}{|c|}{ Provision of Infant formula } \\
\hline No & 10 & 20.0 & 16 & 26.0 & 26 & 23.30 & \multirow{2}{*}{0.47} \\
\hline Yes & 40 & 80.0 & 46 & 74.0 & 86 & 76.80 & \\
\hline \multicolumn{8}{|c|}{ Exclusive breastfeeding until the sixth month } \\
\hline No & 27 & 54.0 & 32 & 52.0 & 59 & 52.70 & \multirow{2}{*}{0.47} \\
\hline Yes & 23 & 46.0 & 30 & 48.0 & 53 & 47.30 & \\
\hline
\end{tabular}

Note: *Chi-square test; Statistically significant **Body Mass Index in accordance with the Organização Mundial de Saúde (OMS, World Health Organization) standard curves [18]. 
number of mothers, $17.0 \%$ reported an absence of guidance about breastfeeding and 18.8\% said they performed no complementary feeding. However, the majority $(67.0 \%$ and $72.0 \%)$ received guidance from nurses. It was observed that the adolescent mothers started weaning more frequently before the seventh month than adult mothers $(p=0.02)$. However, the frequency of early weaning was similar in both groups (Table 2).

The adolescent mothers attained lower responsive $(p=0.04)$ and higher authoritarian $(p=0.01) \quad$ feeding-style scores than adult mothers (Table 3 ). When considering the age of the children, adolescent mothers showed more often responsive styles with children older than 18 months $(p<0.003)$, while adult mothers showed more often passive style with children of the same age group ( $p=0.05$ ) (Table 4).

Table 3. Scores obtained in the inventory of feeding styles of small children by adolescent and adult mothers, in medians and 1st and 3rd quartiles. Recife (PE), 2015.

\begin{tabular}{lcrccc}
\hline Scores of styles & \multicolumn{2}{c}{$\begin{array}{c}\text { Adolescent } \\
\text { mothers }\end{array}$} & \multicolumn{2}{c}{$\begin{array}{c}\text { Adult } \\
\text { mothers }\end{array}$} & $p^{*}$ \\
\hline Responsive & 46 & $43 ; 53$ & 50 & $44 ; 57$ & 0.04 \\
Authoritative & 12 & $10 ; 17$ & 11 & $7 ; 13$ & 0.01 \\
Passive & 7 & $5 ; 10$ & 7 & $5 ; 9$ & 0.57 \\
\hline
\end{tabular}

Note: *Mann-Whitney Test.

Table 4. Scores obtained in the inventory of feeding styles of small children of adolescent and adult mothers and in accordance with the age of the children, in medians and first and third quartiles. Recife (PE), 2015.

\begin{tabular}{|c|c|c|c|c|c|c|}
\hline \multirow[b]{2}{*}{ Scores of Styles } & \multicolumn{3}{|c|}{ Adolescent mothers } & \multicolumn{3}{|c|}{ Adult mothers } \\
\hline & $\begin{array}{l}\text { Children } 9-18 \\
\text { months }(n=40)\end{array}$ & $\begin{array}{l}\text { Children } 19-24 \\
\text { months }(n=22)\end{array}$ & $p^{*}$ & $\begin{array}{l}\text { Children 9-18 } \\
\text { months ( } n=33 \text { ) }\end{array}$ & $\begin{array}{l}\text { Children } 19-24 \\
\text { months }(n=17)\end{array}$ & $p^{*}$ \\
\hline Responsive & $52.9(47.0 ; 56.5)$ & $62.3(53.0 ; 65.4)$ & $0.003^{* *}$ & $59.4(51.8 ; 67.1)$ & $58.82(52.9 ; 65.9)$ & 0.81 \\
\hline Authoritative & $34.3(28.6 ; 51.4)$ & $31.4(31.4 ; 45.7)$ & 0.610 & $31.4(22.8 ; 31.4)$ & $31.40(20.0 ; 48.6)$ & 0.91 \\
\hline Passive & $46.7(40.0 ; 53.3)$ & $53.3(40.0 ; 73.3)$ & 0.190 & $46.6(33.3 ; 50.0)$ & $56.60(40.0 ; 66.6)$ & $0.04^{* *}$ \\
\hline
\end{tabular}

Note: "Mann-Whitney Test; ${ }^{* *}$ Statistically significant.

Table 5. Monthly frequency of intake of food groups of infants and children of adolescent mothers compared with adult mothers.

\begin{tabular}{|c|c|c|c|}
\hline \multirow{3}{*}{ Food Group } & Adolescent Mothers $(n=50)$ & Adult mothers $(n=62)$ & \multirow{3}{*}{$p^{*}$} \\
\hline & Median (Q1; Q3**) & Median (Q1; Q3**) & \\
\hline & Range & Range & \\
\hline \multirow{2}{*}{ Breads and cereals } & $30(3.93 ; 30)$ & $30(3.93 ; 30)$ & \multirow{2}{*}{0.51} \\
\hline & $0-30$ & $0-30$ & \\
\hline \multirow{2}{*}{ Fruits and vegetables } & $0.9(0 ; 3.93)$ & $0.9(0 ; 3.93)$ & \multirow{2}{*}{0.49} \\
\hline & $0-30$ & $0-30$ & \\
\hline \multirow{2}{*}{ Meat, offal, eggs, and beans } & $30(16.9 ; 30)$ & $30(16.9 ; 30)$ & \multirow{2}{*}{$0.05^{* * *}$} \\
\hline & $0.45-30$ & $2-30$ & \\
\hline \multirow{2}{*}{ Milk and dairy products } & $16.9(16.9 ; 30)$ & $16.9(15.1 ; 30)$ & \multirow{2}{*}{0.12} \\
\hline & $2-30$ & $0-30$ & \\
\hline \multirow{2}{*}{ Sugars, fats, and sweets } & $3.9(1.8 ; 17)$ & $3.0(0.9 ; 15.1)$ & \multirow{2}{*}{$0.02^{* * *}$} \\
\hline & $0-30$ & $0-30$ & \\
\hline \multirow{2}{*}{ Industrialized food } & $3.9(1.8 ; 15.4)$ & $15(1.8 ; 17)$ & \multirow{2}{*}{0.22} \\
\hline & $0-30$ & $0-30$ & \\
\hline
\end{tabular}

Note: "Mann-Whitney Test; ${ }^{* *}$ Q1; Q3; first and third quartiles; ${ }^{* * *}$ Statistically significant. 
Table 5 compares the medians, interquartile range, and variation in the frequency of monthly intake of six food groups among the children of adolescent and adult mothers. There was a higher frequency of intake of sugars, sweets, and fats $(p=0.02)$ and a lower intake of meat, beans, offal, and eggs by children of adolescent mothers $(p=0.05)$. A low intake of fruits and vegetables was observed in both groups.

\section{DISCUSSION}

In this study, we observed that adolescent mothers have less responsive and more authoritarian feeding styles than adult mothers and, interestingly, the age of the child also contributes to modifying the feeding style of their mothers. Adolescent mothers are more likely to establish a responsive style of feeding with their older children and adult mothers are more inclined to adopt a more passive style with their older children, as well.

The relationship of child's age with the feeding style adopted by the mother can be explained, probably, because feeding is an act that reflects the reciprocity between the dyad mother-child. Actually, reactive behavior and emotional support in relationship between parents, caregivers and child changes with age $[7,20]$. This phenomenon, likely, is also reflected in feeding.

In addition, others aspects associated with the psychosocial vulnerability of adolescent mothers might interfere in the establishment of this relation of feeding care. A study with 160 mothers of children between 3-18 months that evaluated psychosocial determinants in the maternal styles of feeding, demonstrated that self-esteem and obesity were significantly associated with pressure and restriction on feeding their children [8].

In the present study, interestingly, the adolescent mothers had a frequency of exclusively breastfeeding at the sixth month similar than adult mothers, unlike what is reported in most published studies. Early weaning in adolescence has as determinant factors low schooling and low socioeconomic levels, in addition to inadequate maternal and prenatal nutrition [21]. However, in this group adolescent mothers were accompanied in basic health units, and belonged to the same communities and with similar socioeconomic backgrounds as adult mothers. Then, in this special circumstances, the adolescent mothers, possibly also had prenatal follow-up similar to adult mothers, favoring the practice of breastfeeding.

On the other hand, the initiation of solid and semi-solid foods was earlier among adolescent mothers, as demonstrated in studies conducted in Ethiopia and India [22,23]. In a previous study of mothers between the ages of 14 and 19 with children from seven to 11 months, in Recife, the provision of liquefied food was higher among adolescent mothers and the authors discussed that these mothers elected this preference due to be easy the provision of food with this consistency [11].

It is known that education and support to mothers by health professionals are important, both for the time of introduction and the adequacy of complementary feeding, besides cultural and social factors [23]. However, the rate of orientation about feeding by health professionals was only of $80 \%$ among adolescent mothers, perhaps insufficient to modify their attitudes.

When food intake was analyzed as part of feeding practices, it was found that adolescents offered more sweets, sugars, and salty foods to their children. These data had been previously found in another study in Northern Brazil [2]. Likewise, we observed that the intake of fruit and vegetables was, generally, very low. A variety of factors play an important role in the acceptance of fruit and vegetable by children, including the feeding practices of parents during childhood, parental preferences, availability, accessibility, and the environment of offer and intake of fruits and vegetables by parents [21]. It is possible that, in 
the group evaluated, socioeconomic and cultural factors do not favor the choices and access to fruit and vegetables.

Positive parental practices are associated with more favorable health conditions among children [24], and negative practices can increase the intake of inadequate food and those with high calories $[25,26]$. Several studies have suggested that the way parents feed their children has a strong relationship with childhood obesity. This fact is explained because the use of restrictive, coercive or punitive methods may changes the control of hunger and satiety of the child and leading the feeding to be a moment of anxiety and frustration [26]. It is possible that adolescent mothers adopt unsuitable eating practices by lack of skill in feeding interaction with the infant, demonstrating emotional insecurity upon the child's behavior at mealtime [25].

Two considerations deserve attention regarding the objectives of the present study. First, there is a scarcity of studies that evaluate the styles of adolescent mothers feeding their children and secondly, there is no "gold standard" for classifying these styles, besides empirical evidence corroborates associations between positive parenting feeding practices and healthier eating behaviors [6], which was a limitation of this study. Ultimately, our findings suggest that motherhood during adolescence has a higher risk of adoption of unresponsive practices and food styles, and it is related to inadequate food intake patterns during the complementary feeding of their infants.

\section{CONTRIBUTION}

KAO COSTA and GAP SILVA: Conception and design, analysis and interpretation of data, review, and approval of the final version of the article. MMC ANTUNES: Analysis and interpretation of data, review, and approval of the final version of the article. PC CABRAL: Analysis and interpretation of data from food intake, review, and approval of the final version of the article.

\section{REFERE N CE S}

1. Alves H, Walker P. Educação alimentar e nutricional como prática social. Demetra. 2013;8(3):499-508.

2. Oliveira AS, Silva VA, Alves JJ, Fagundes D, Pires ISC, Miranda LC. Mães e amamentação versus hábitos alimentares de pré-escolares. Alim Nutr Araraquara. 2013;23(3):377-86.

3. Silva AS, Alves DA, Santiago Lemos ICS, Albuquerque GA. Alimentação complementar em menores de um ano: interpretações de mães adolescentes. Rev Saúde Desenv. 2016:9(5):93-105.

4. Steinsbekk S, Belsky J, Wichstrom L. Parental feeding and child eating: An investigation of reciprocal effects. Child Dev. 2016;87(5):1538-49.

5. Carozzo NPP, Oliveira JHA. Comportamento alimentar: um estudo da relação entre IMC de crianças e sua percepção sobre as práticas alimentares parentais. Est Inter Psicol. 2015;6(1):21-35.

6. Larsen JK, Hermans RCJ, Sleddens EFC, Engels RCME, Fisher JO, Kremers SPJ. How parental dietary behavior and food parenting practices affect children's dietary behavior. Interacting sources of influence? Appetite. 2015;(89):246-57.

7. Black MM, Aboud FE. Responsive feeding is embedded in a theoretical framework of responsive parenting. J Nutr. 2011;141(3):490-4.

8. Barrett KJ, Thompson AL, Bentley ME. The influence of maternal psychosocial characteristics on infant feeding styles. Appetite. 2016;(103):396-402.

9. Schwartz C, Scholtens PA, Lalanne A, Weenen $\mathrm{H}$, Nicklaus S. Development of healthy eating habits early in life: Review of recent evidence and selected guidelines. Appetite. 2011;57(3):796-807.

10. Madigan S, Wade M, Plamondon A, Vaillancourt K, Jenkins JM, Shouldice M., et al. Course of depression and anxiety symptoms during the transition to parenthood for female adolescents with histories of victimization. Child Abuse Negl. 2014;38(7):1160-70.

11. Lima APE, Javorski M, Amorim RJM, Oliveira SC, Vasconcelos MGL. Práticas alimentares no primeiro ano de vida: representações sociais de mães adolescentes. Rev Bras Enferm. 2014;67(6):965-71.

12. World Health Organization. Indicators for assessing infant and young child feeding practices: Conclusions of a consensus meeting held 6-8 november 2007 in Washington (DC). Geneva: WHO; 2008.

13. Carvalhaes MABL, Perosa GB, Silveira FCP. Comportamentos maternos e infantis durante a alimentação: estudo mediante observação. Rev Ciênc Cuid Saúde. 2009;8(3):411-8. 
14. Alvarenga P, Malhado SCB, Lins TCS. O impacto da responsividade materna aos oito meses da criança sobre as práticas de socialização maternas aos 18 meses. Estud Psicol (Natal). 2014;19(4):305-14.

15. Oliveira JM, Castro IRR, Silva GB, Venancio SI, Saldiva SRDM. Alimentação complementar: proposta de indicadores e de instrumento. Cad Saúde Pública. 2015;31(2):377-94.

16. Fórnes NS, Martins IS, Vélaquez-Meléndez G, Latorre MRDO. Escore de consumo alimentar e níveis lipêmicos em população de São Paulo, Brasil. Cad Saúde Pública. 2002;36(1):12-8.

17. Ministério da Saúde (Brasil). Secretaria de Políticas de Saúde. Guia alimentar para crianças menores de dois anos. Brasília: Ministério da Saúde; 2011.

18. Ministério da Saúde (Brasil). Secretaria de Atenção à Saúde. Orientações para a coleta e análise de dados antropométricos em serviços de saúde: Norma Técnica do Sistema de Vigilância Alimentar e Nutricional: SISVAN. Brasília: Ministério da Saúde; 2011.

19. Alvarez ML, Wurgaft F, Salazr ME. Mediciones del nivel socioeconómico bajo urbano en familias con lactante desnutrido. Arch Latinoam Nutr. 1982;32(3):650-62.

20. Vollmer RL, Mobley AR. Parenting styles, feeding styles, and their influence on child obesogenic behaviors and body weight: A review. Appetite. 2013;71(1):232-41.
21. Blissett J, Bennett C, Fogel A, Harris G, Higgs S. Parental modelling and prompting effects on acceptance of a novel fruit in 2-4-year-old children are dependent on children's food responsiveness. Br J Nutr. 2016;115(3):554-64.

22. Ayana D. Complementary feeding practices among children in Benishangul Gumuz Region, Ethiopia. BMC Res Notes. 2017;10(1):335-42.

23. Hackett KM. A qualitative study exploring perceived barriers to infant feeding and caregiving among adolescent girls and young women in rural Bangladesh. BMC Public Health. 2015;15(1):771-8.

24. Ray C, Kalland M, Lehto R, Roos E. Does parental warmth and responsiveness moderate the associations between parenting practices and children's health-related behaviors? J Nutr Educ Behav. 2013;45(6):602-10.

25. Fiese BH, Bost KK, McBride BA, Donovan SM. Childhood obesity prevention from cell to society. Trends Endocrinol Metab. 2013;24(8):375-7.

26. Fiese BH, Bost KK. Family ecologies and child risk for obesity: Focus on regulatory processes. Fam Relat. 2016;65(1):94-107.

Received: July 4, 2017

Final version: November 17, 2017

Approved: January 5, 2018 